\title{
Proceeding
}

9th INSHS International Christmas Sport Scientific Conference, 4-6 December 2014. International Network of Sport and Health

Science. Szombathely, Hungary

\section{Learner-centred teaching methods in PE. Processing athletics teaching material in project method}

\author{
JUDIT H. EKLER \\ University of West Hungary, Department of Sport Science, Szombathely, Hungary
}

\begin{abstract}
Ekler, J.H. (2015). Learner-centred teaching methods in PE. Processing athletics teaching material in project method. J. Hum. Sport Exerc., 9(Proc1), pp.S236-S246. We would like to present the methodological experience involves the participation of 11 teachers with their 20 classes of different grades each, within a period of 4-6 weeks. Processing the athletics teaching material was performed by adopting the project method and clustering around two project titles: 'Peasant Olympics' (9 projects), and 'Approaching Athletics' (11 projects). Contents outside the PE class and school environment were in the limelight. Differentiating was main focal point, just like individual activity and volunteering. Pupils performed tasks on their own, in group and on class level. The students' vitality increased in the field of motion and other activities. Because other subjects and fields of activity were involved in the framework of a PE lessons, students who had never been proactive, in this process have become so. In many fields of activity - of course in motion activities as well- differentiation became obvious. Therefore, the various activities in the project provided for many students chances of success, perhaps more than in a usual routine. The individual work, the cooperative solutions between students and external relationship-building was a characteristic of the process. Isolation of school classes was solved by project activity. Connecting different fields of science can raise understanding, the awareness, thus connecting sciences to real life. In this synthesis many teachers of other majors helpfully supported the PE teacher. It was hard for the teachers on the other hand, to get used to the helpful, supportive role demanded by the project-method, instead of the common 'boss role' which was usual. Key words: METHOD EXPERIENCE, DIFFERENTIATION, HAPPY EXPERIENCES.
\end{abstract}

\footnotetext{
Corresponding author. University of West Hungary ,Bajcsy-Zsilinszky street, Sopron 9400 Hungary

E-mail:hekler@mnsk.nyme.hu

9th INSHS International Christmas Sport Scientific Conference, 4-6 December 2014. International Network of Sport and

Health Science. Szombathely, Hungary.

JOURNAL OF HUMAN SPORT \& EXERCISE ISSN 1988-5202

(c) Faculty of Education. University of Alicante

doi:10.14198/jhse.2015.10.Proc1.11
} 


\section{INTRODUCTION}

In the $21^{\text {st }}$ century, projects have become educational and instructional devices applied with increasing frequency at school, whereas the method is teaching material processed by project method. Whether assessing from a teaching process aspect or by viewing the teachers or students, applying project work is appealing by several beneficial traits.

Irrespective of the grade of school we use a project at students will enjoy the task-oriented and activitycentred organization of their work as it offers variety from the routine. Project activity is motivating by itself due to its interactive character. The synchronic activity lead on several streams will get them immersed into the well-known world of their spare time activities they are keen on (e.g. cyber games).Project-oriented learning approaches the topic or task from a broader scope and in a complex manner, far beyond that of the framework of interpretation of a particular subject. This interdisciplinary approach will often make more tangible and real a teaching material so often isolated in its kind. (Kovátsné Németh, 2006). Projectoriented learning is in many cases developed outside the school. It is not seldom that persons out of the range of school are involved into the project work which will further enhance the connection between the material studied and the reality. We have already mentioned the motivating character of the novelty in the teaching material. Further on, it is appealing for the students to work together meanwhile accomplishing the project task. The opportunity to participate in this joint work is beneficial; it is according to their personal field of interest, often rhyming with the person's abilities and inclinations. Joint target, planning, gathering new experience and scouting for new information in the course of completion, the chain of individual and group decisions ultimately result in real creative activity.

For a teacher, working in project is a remarkable challenge. Teaching in this manner is real adventure. The role of a moderator, observer, partner, advisor, assisting person, sometimes a mediator in the course of project activity is stable position to avoid stereotypes. These make teaching by routine impossible, thus offering novelty to the teachers themselves. The course of processing the teaching material cannot be forecasted in its entirety; accordingly, it cannot be scheduled beforehand. This is why active and differentiated connection registers are required both in student to student and also in teacher-students relations. Besides educating the talented and proactive children, this kind of differentiated student-teacher relationship will bring about higher efficiency in the education of students more difficult to handle (M. Nádasi, 2003).

Project work as process-oriented teaching is perfect to train learning strategies. It enhances individual work of the student in acquiring information, increases the rate of self-control and regarding intrinsic motivation in learning, which, in the age of "lifelong learning" is priority objective in school work. The process by which students work up actively the material tailored to them and are not passively submissive to being developed (Hortobágyi, 2003), may well ground successful adult activity

\section{EXPOSING PROBLEMS}

When thinking over and recognizing the values of project teaching, analysing the benefits and traits of project pedagogy, several issues arise. Is project method teaching appropriate as a teaching method for any kind of teaching material? Can it be successfully applied as a method or principle for any or all the teachers? Is this method operational in teaching PE?

In Hungary the method runs with big, spectacular sports and PE project schemes, often lasting for weeks and comprising all student classes of a specific age, at least, sometimes involving whole schools. 
Examples for this are the week dedicated to health, the Olympic project, or the sports week. Common attribute of these is campaign feature-a surplus to regular teaching activity, often dealing with a particular topic range or some selected problems, instead of teaching and learning within a project period (Fehérné, Cséve 2009; Kovács, 2009). Observing the international practice, the range is vast when examining the PE projects offered (Bover, 2012; PE project). These projects embrace a project period usually longer than our domestic project lifetime (half a year, a whole school year)and basically focus on individual or small group activities. A common feature of these is relying to a high extent on student autonomy and also accurate monitoring of individual progress records. Although the schooling system in different countries displays a wide spectrum lacking uniformity even in general terms, this is emphatically true for the areas of sports and PE at school as a discipline of culture and activity. As it regards foreign sports and school PE training projects, these are reality-based mostly, and less connected to curricular activity at school. Except for the big project schemes mentioned above at school level, there are hardly any cases when the project itself is worked up as teaching material in the Hungarian special methodology literature. Hajagos and Hamar (2008) reporting about the circus-project is pioneers' work in the Hungarian special literature.

My opinion is that a project can be a simpler, 'ordinary', and by this, a more regularly applied processing of the teaching material. This simple project - let's say 'ordinary PE project' - fits perfectly into the educational-pedagogical process. First of all, it is so because proportioning by 3-4-6 weeks long cycles with project logics is a recognized practice in the Hungarian PE education. Thinking in projects, alas, can renew PE classes from many aspects. Versatile approach of the chosen topic can activate the children for a differential, self-dependent and creative work. It sets measuring as a possible, moreover, inevitable means at the beginning and the ending of the project, keeping track of personal development, and is used as an engine of personal progress. Coupling the motion material of the project with other kind of information from different fields can help realizing and understanding the cause and effect. By this it can be a device of attitude- and lifestyle forming beyond the actual motivation.

Adoption of advantageous and useful elements of good practice and method, applied successfully abroad, would be beneficial for the Hungarian relations. It would be desirable to instruct and adopt the new methodological possibilities - although we know that project education is not a recent education strategy, since it has a history of more than a hundred years - for the entrant PE teachers so they can rely on experiences gained during work.

The aspects unfolded above launched a methodological experiment series ongoing from 2008, PE material processed by project method. We reported about the experiment and achievements in several studies (H.Ekler, 2011a, 2011b, 2013). In the present study we introduce the processed teaching material and the 'ordinary project' as well. I wish to note that our projects are endeavours carried out with great enthusiasm, achievements and mistakes alike, analysed throughout the report. Processing athletics teaching materials by project method was handled by $11 \mathrm{PE}$ teachers in 20 classes. Materials and processes introduced here are not part of only one project, just examples, settling methods and activities from all athletics-themed projects.

\section{MATERIAL AND METHODS}

The aim of the 'athletics project'

We can define the aim of processing teaching materials by 4-5 week long projects from several aspects. The direct objective of the selected project title is to acquire the teaching material of the year in experimental classes: athletics races (relay race, flat-race from $60 \mathrm{~m}$ to $2000 \mathrm{~m}$ ), jumps (long jump, high 
jump, triple jump) and discus, javelin and hammer throw, with the particular contents respective of the classes taught. This includes aimed development of the abilities and skills, improvement of the technique and competition skills. The indirect goal - which serves the efficient accomplishment of the direct objective - is to create such motivating environment in which the exercise becomes a fascinating challenge, connects to the 'real world' with many strings, provides new knowledge and offers every project participant the opportunity of successful motoric activity. We have to mention another long-run objective. PE teachers working in the project experiences raised interest and activity in sports and PE from every participant connected to the school (students, teachers, parents) - although this wasn't planned in advance during dealing with everyday tasks. We can therefore raising the bar in the context of evaluating and judging PE as a subject matter.

\section{Participants}

The methodological experience involved the participation of 11 teachers with their 20 classes (471 students) of different grades each, within a period of 4-5 weeks.

\section{Procedures}

Processing the athletics teaching material was performed by adopting the project method and clustering around two project titles. One was the 'Peasant Olympics' (9 projects), the other was the 'Approaching Athletics' (11 projects). The titles were defined by PE teachers/colleagues in little groups, because in this case it was about an 'ordinary project' where the project served as a method for processing the athletic theme teaching materials. Contents outside the PE class and school environment were in the limelight. Differentiating was main focal point, just like individual activity and volunteering. Pupils performed tasks on their own, in group and on class level.

To evaluate project efficiency, we applied two assessment devices. 1. Qualitative progress evaluation by means adequate to the teaching material (result data sheet, motor tests). 2. Guided observation of individual motivation.

\section{RESULTS}

The activities and content of the project process can be described by presenting our results.

\section{'Brain storming'}

As a first step, the classes began brainstorming in form masters' or PE classes, during day care or at mass sport events. The teacher made it clear that the aim of the project is to acquire new knowledge in the theory and practice of a particular theme, to develop abilities and skills in those fields. After raising the title of the project, students were listing activities, knowledge, connections, persons, events, associations etc. The depth of these knowledge and ideas were influenced by the class itself. These ideas were collected on boards, wrapping papers and papers, then they arranged them; those activities, programs remained which were decided as the most interesting/achievable by common wisdom. This moment of planning was the most important section for the teachers as the section which required strong control. This process - in the opinion of our teachers - was difficult yet most effective at the same time.

Difficult, since transferring the motion into subject of a discussion meanwhile moderating it was a new task for them; and surprisingly effective since at the end they had to reach conclusions the focus of which was motoric activity in the scope of the chosen topic. However, they experienced that it was easy to collect new 
ideas from the children, some being quite surprising for the teacher, the adult. Many times, good ideas enriched the program providing from students who were less successful in motoric activities.

Project-mapping and timeline

Table 1. Project-map - "Peasant Olympics"

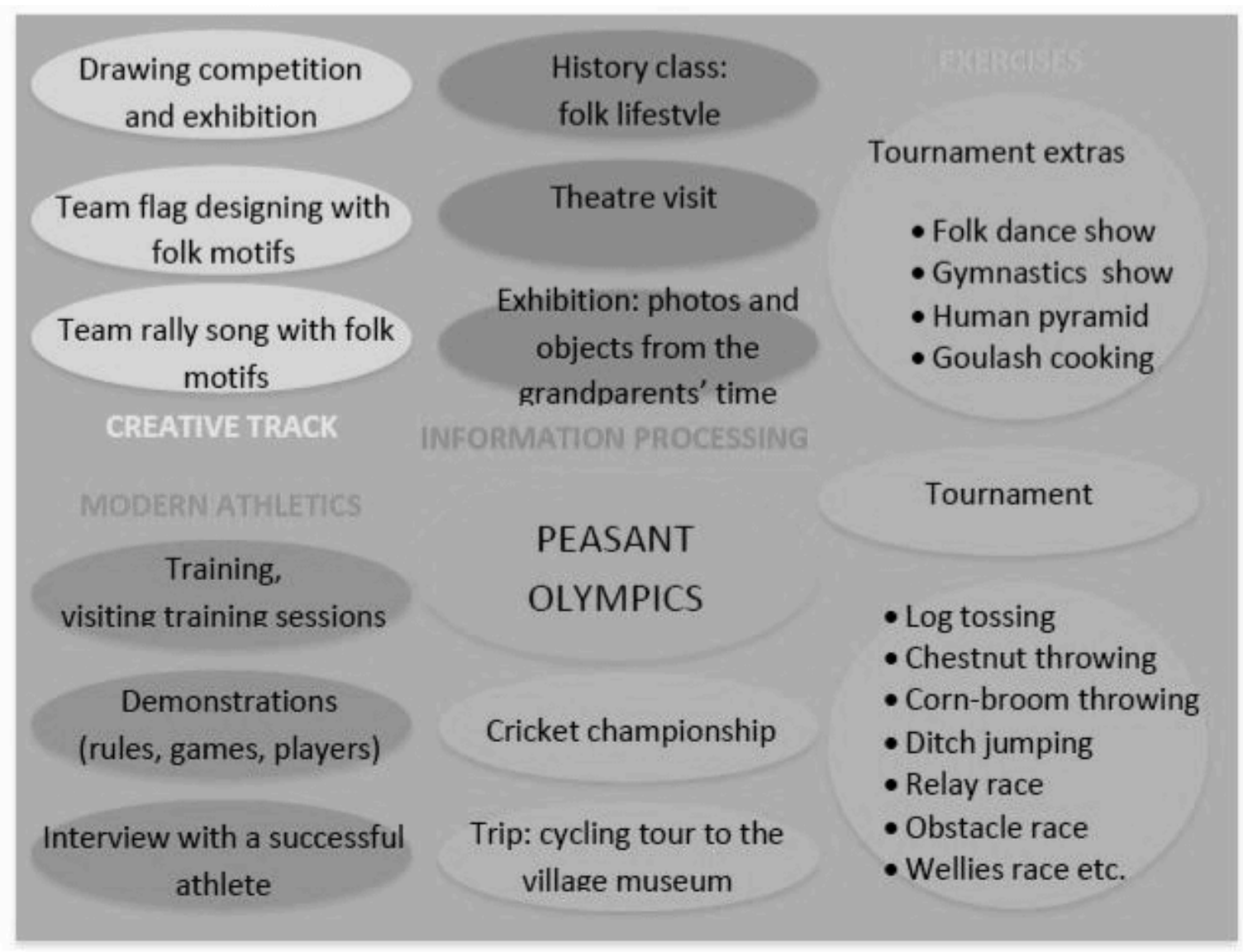

Notes: from teacher Selmeczi's project, 2011

Planning, personal responsibility, and publicity are important elements of processing the teaching material by project method. Hence, numerous documents were compiled to introduce the project-content and to back planning and performance. The project map (see table 1) helps the logical process of the topic and raises the interest, serves as sustaining motivation. In drawing creative students in IT showed excellence. This was the first opportunity for cooperation between classes (drawing, visual culture, IT), for involving colleagues of different other majors.

The project map was placed in classrooms or boards appeared along the corridors, attracting the attention of other, non-participating classes. The activities were performed during the given period (3-5 weeks) the PE classes, free-time sport activities and even for surplus dates. The PE teachers had the most important role considering professional and organizing aspects. To particular activities, persons responsible for the tasks were ordered - with regard to PE classes - and the reachable aims were defined. 
Contents of the 'athletics projects'

'Peasant Olympics'

The main objective of the project was to process the teaching material which meant performing skillsimproving exercises -including struggling exercises based on natural forms of movements- within the scope of lessons, learning new techniques (e.g. flinging motion), practice and polish already known forms of motions (e.g. long jump with hollow back technique). Rules of the involved events were also surveyed. The PE class activity was completed by athletics training and contest (as contestant or spectator). By practicing different athletics exercises, the students prepared for the project-closing 'Peasant Olympics', a day of sport activities. According to the local facilities and students ideas, the following events took place:

$-6 \mathrm{x} 400 \mathrm{~m}$ relay race in wellies, with corncob staff

-Bole and sack carrying (carpet carrying) contest - relay race

-Barrow carrying contest, barrow-slalom - relay race

-Water carrying relay: carrying 201 water in the marked course - relay race; the team which saves the most water earns extra points

-Rolling-pin throwing: 1st teammate throws the rolling-pin, the 2nd throws from where it had fallen etc... the team with the longest throws gets the most points

-Domestic animal shepherding: driving 3 kinds of balls (hand-, basket-, and small ball) by foot around the buoy and back

-Sawing: sawing to time

-Broom throwing (see figure 1)

-Pot lid throwing: 'peasant discus'

-'Ditch-jumping'

-'Haycock-pole holding'

-'Homewards from the pub: cycling in zigzag and obstacle track, a time-based activity

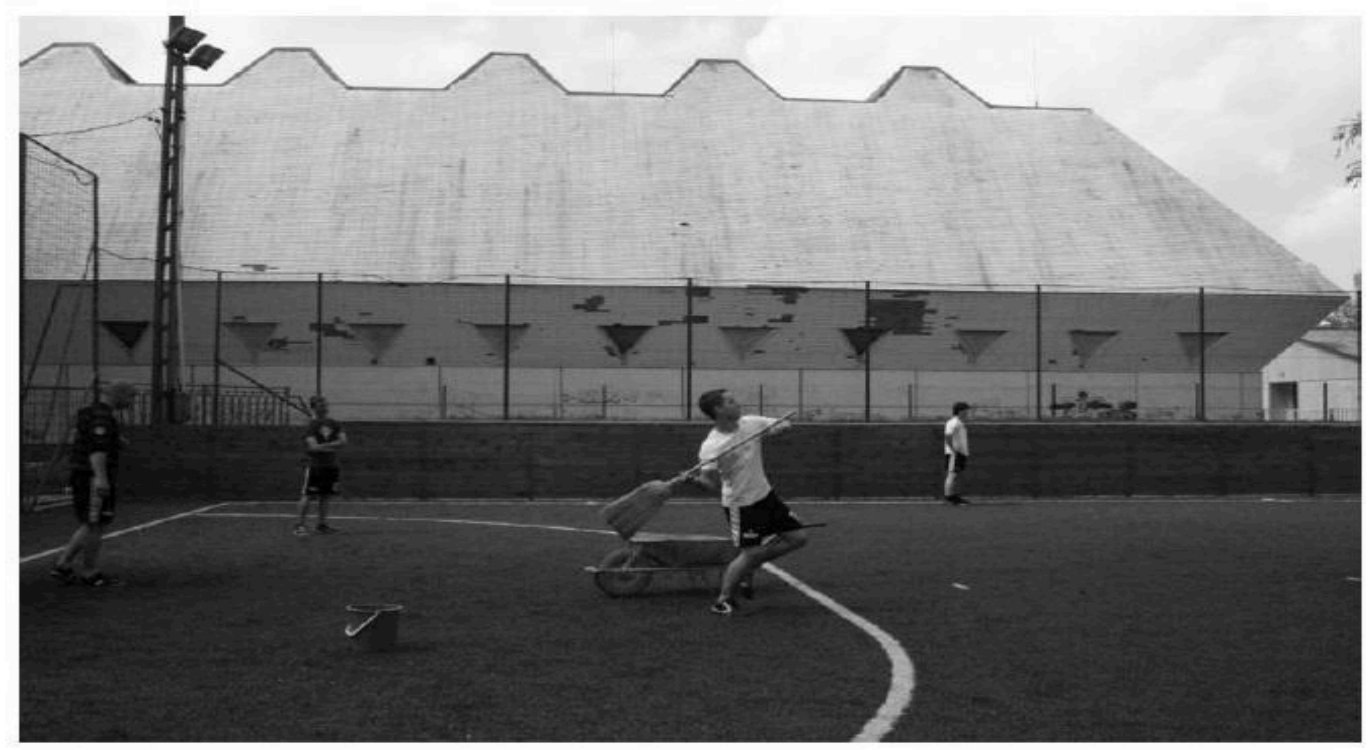

Figure 1. Broom throwing - "peasant javelin" 
Table 2. IT class work relating to the "Peasant Olympics"

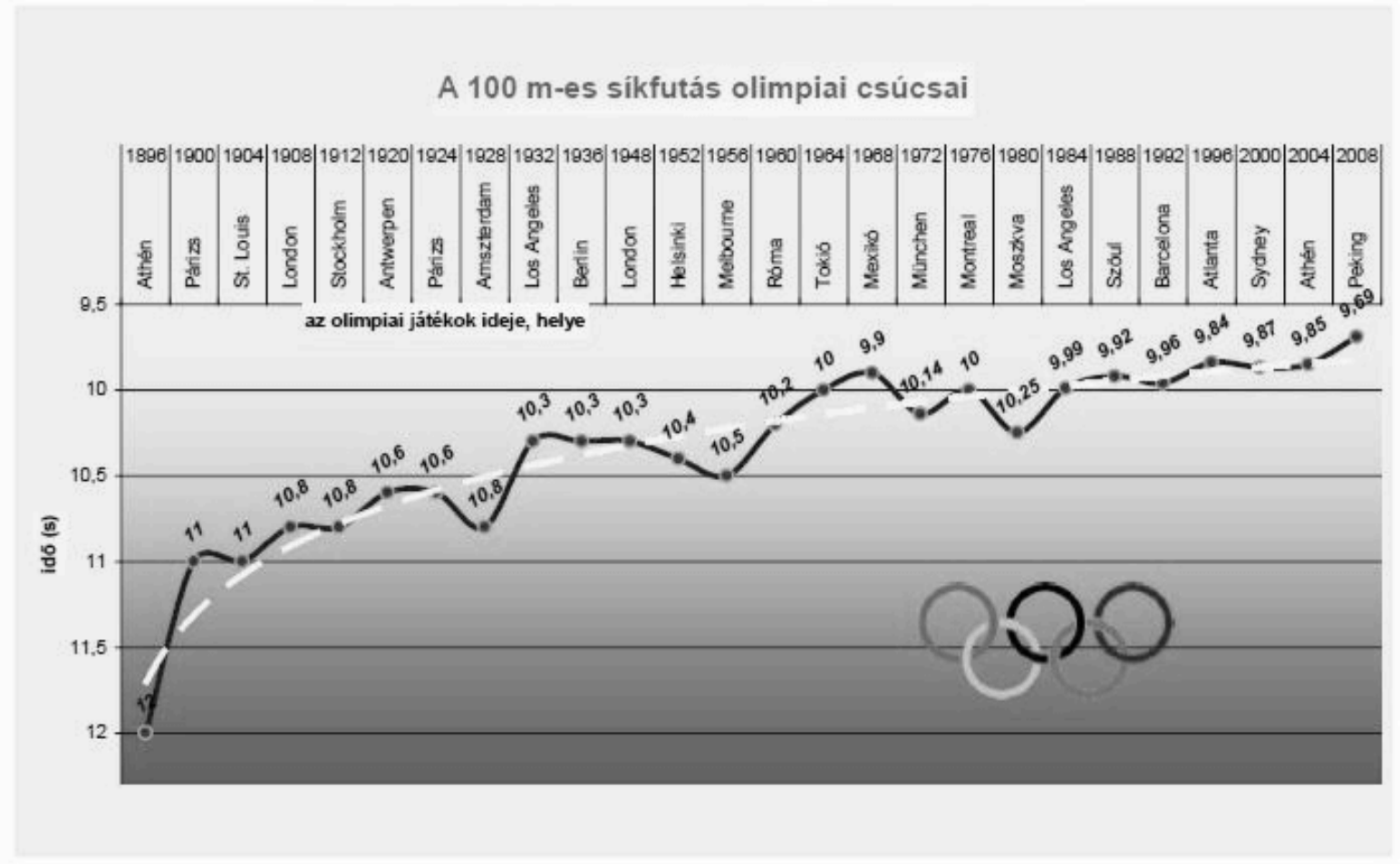

Notes: The title of the table is: $100 \mathrm{~m}$ dash olympic records

From teacher Ms L.Varga Csótár's project, 2011

Relating activities: opportunities had been offered to twin in the project, e.g. studying country life and culture in literature (e.g. Toldi, poems of Petőfi), music or in history lessons. Some classes visited a village museum or ethnographic gallery in the project period. Some arranged it within a cycling tour. Within the scope of arts and visual culture class they set up an exhibition of ethnographic objects, others explored the topic by drawing thus closing the exhibition. During IT classes they collected and processed the data pertinent of the topic (see table 2). People indirectly connected to school (alumni, family members, acquaintances) also participated in the project. An interview was made with a high-ranking Olympic athlete or a conversation was organised. They collected ethnographic objects from family members, villagers and inquired about folk games, rural feats of valour.

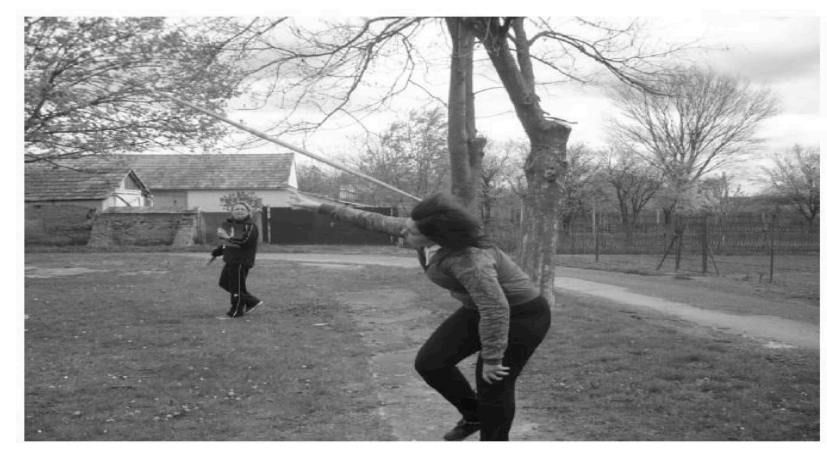

Figure 1. First tryings with javelin throwing. From teacher Straub's project, 2012 


\section{'Approaching Athletics'}

The project gave an opportunity to process the athletics material more directly than the 'Peasant Olympics'. ' $C$ ' (i.e. adapting the project method) gave a framework for learning the current athletics movements, which was attained by extracurricular sport club activities and objected an aim -usually appearing as a home championship - which weighted the success of the accomplished material. In several places efforts were made to get familiar with such athletics movements which were unusual in school practice. This is how the javelin (by the old instrument of a villager) and grenade throwing came into the project. The students have also collected wide theoretical knowledge during the project (about the events, rules, domestic and foreign results etc.). The following events - in harmony with age and opportunities - took place in the project closing home championship:

$-400 \mathrm{~m}$ walking

-Running: $60 \mathrm{~m} ; 60 \mathrm{~m}$ hurdle; $400 \mathrm{~m} ; 800 \mathrm{~m} ; 4 \times 400 \mathrm{~m}$ relay; $2000 \mathrm{~m}$

-Jumping: long jump, triple jump, high-jump

-Throwing: small ball, grenade, javelin (see figure 2), shot put

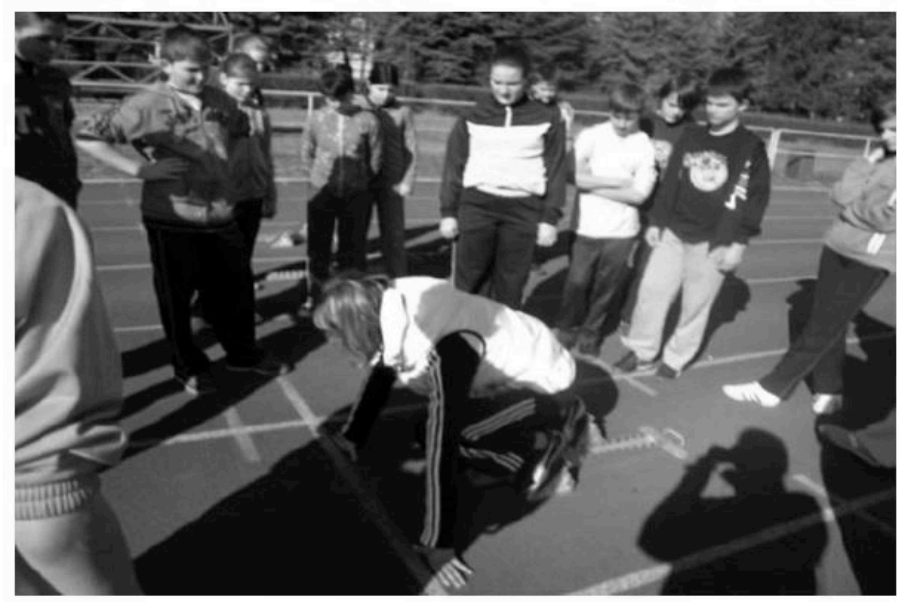

Figure 3. Visit an athletics track. From teacher Horvath's project, 2012

Relating activities: The project gave opportunities to subject relations and to gain experience out of school. In history class they treated with the history and famous figures of athletics' (e.g. Pheidippides). In math and physics class the principles of athletics events were discussed (e.g. askew throwing) and they did counting exercises with athletics result numbers. In biology the working of striped-striated muscles was educated. The out-of-school people initiated in the project are all athletics professionals: trainers, athletes, judges. The visiting of the county-seat's rekortan athletics centre was the significant event of the project of several classes (mostly from the countryside schools) where they also had the opportunity to train (see figure 3 ).

The students have presented the results of their individual our group collecting-work by exhibitions; short lectures (see figure 4). These events, along with the home championships, have raised the attention of the out-of-project classes. The project participant students became admired and envied persons. 


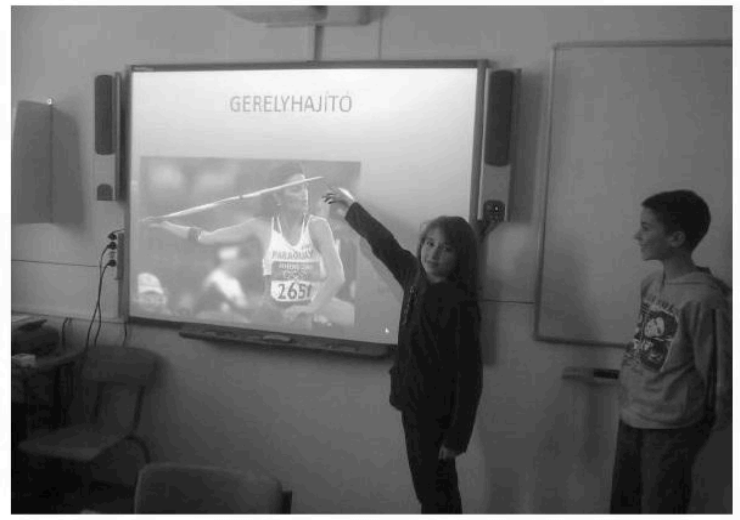

Figure 4. From teacher Horvath's project, 2012

Valuation in the 'athletics projects'

The valuation which maintains the motivation for learning and ensures the right self-esteem in the same time is not an easy, but a necessary task in any subject. As of the PE culture, the matter of assessment and benchmarking is transmissibly complex (we evaluate the absolute performance, the performance compared to themselves, the attitude), and becomes even more complicated by the projects values based on voluntary undertaking, differentiated individual or group work nevertheless are also aspiring for improving the performance.

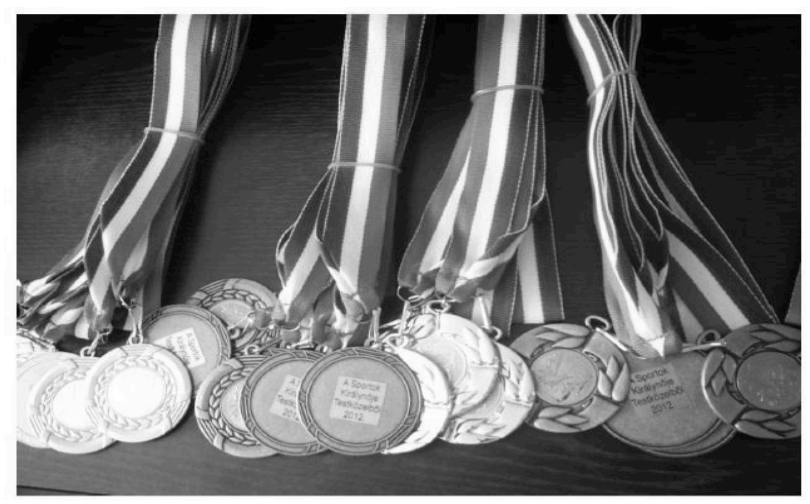

Figure 5. Medals from the host competition "Athletics sports at close quarters" From teacher Horvath's project, 2012

During the projects the PE teachers applied continuous individual valuation by words, group valuations and they rewarded with good grades the appropriate performances showed during the contests (see figure 5). These were also reciprocally rated positively. Those, who showed good performances absolutely or when compared to themselves, were rewarded. There was little ground for criticisms when someone completed the undertaken tasks poorly or not at all. They barely seized the opportunities of self-checking and checking each other (students), which could result in developing interpersonal communication culture and forming a community. Even later on, the colleagues leading the project showed uncertainty in the matter of valuation; they considered it difficult, problematic. 


\section{DISCUSSION}

Although it was obvious for every PE teacher that certain elements of processing the teaching material by project method often appear in classes - for example, 3-6 week scheduling by the main topic, raising the awareness for biomechanics or physical laws in motions, connection with other sport activities, etc. - yet the teachers started the experiment with certain concern. During the project and when organizing the process they gained positive experience. They experienced that even raising the idea of a project, due to its challenge, novelty and versatility it was motivating for every student. Our colleagues had no problem making the students busy, and they gained useful experience.

The students' vitality increased in the field of motion and other activities. Because other subjects and fields of activity were involved in the framework of a PE lessons, students who had never been proactive, in this process have become so. In many fields of activity - of course in motion activities as well- differentiation became obvious. Therefore, the various activities in the project provided for many students chances of success, perhaps more than in a usual routine.

The individual work, the cooperative solutions between students and external relationship-building was a characteristic of the process. Isolation of school classes was solved by project activity. Connecting different fields of science can raise understanding, the awareness, thus connecting sciences to real life. In this synthesis many teachers of other majors helpfully supported the PE teacher. It was hard for the teachers on the other hand, to get used to the helpful, supportive role demanded by the project-method, instead of the common 'boss role' which was usual.

Within the process, the measuring/valuating was the least effective element. We have to create the opportunity for individual measuring, the simple devices to assess with ease not only in the field of abilities, but also on knowledge regarding motion. We have to increase the students' routine in self-evaluation and valuating other students, too. In some projects, the proportion of motion-related side activities (presentations, visits, drawing, etc.) overdid the desirable ratio. It is worth reminding that the main objective of PE projects is the motion itself, i.e. to acquire and exercise new motion-forms.

\section{CONCLUSIONS}

Our opinion is that it is useful to consider project-method based teaching as a possible method, although there are undiscovered fields too. Because the self-activated, planned work is the leading motif of the project, it could be better to base the project on the students' independent activities, even on activities at home. With enough motivation, follow-up and measurement of personal development, motion activities can be carried out as 'homework'. By this, we can get closer to the long-term objective of PE teaching: creating the need for an active, healthy lifestyle, which is full of motion and to acquire the knowledge to do so.

\section{REFERENCES}

1. Bover C. (2012). Stay healthy!! PE project http://oaklandtech.com/staff/cbover/pe-project-6/ (Download: 2014.11.13.)

2. Ekler J.H. (2011a). Módszertan testnevelés tanítása tárgyból, projektmódszer felhasználásával. In.: Záró tanulmányok a Pedagógiai szolgáltató és kutató hálózat kialakitása a pedagógus-képzésben a nyugat-dunántúli régióban címü projekt eredményeiböl. Szombathely, pp.48-66. 
3. Ekler J.H. (2011b). PE project. InHughes, M., Dancs, H., Polgar, T., Nagyvaradi, K., Sporis, G., Vuckovic, G., \& Jovanovic, M. (Ed.), Research Methods and Performance Analysis. Publisher. University of West Hungary.

4. Ekler J.H. (2013). Új módszertani lehetőségek a testnevelésben és a testnevelő tanár képzésben. In. Karlovitz J.B., Torgyik J.(szerk.) Vzdelávanie, vyskum a metodológia (Oktatás, kutatás és módszertan) International Research Institute s.r.o. Komárno.

5. Fehérné C.E. (2009). Egészséges, mint a makk. Projektprogram.Helgerud, J., Engen, L.C., Wisloff, U., \& Hoff, J. (2001). Aerobic endurance training improves soccer performance. Med Sci Sports Exerc., 33(11), pp.1925-1931.

6. Hajagos L., \& Hamar P. (2008). Projektoktatás és cirkuszprojekt I.-II. rész, Cirkuszi akrobatika, I. évf. 1. és 2. szám

7. Hortobágyi Katalin (2003): Projekt kézikönyv. Iskolafejlesztési Alapítvány, ALTERN füzetek 10. Budapest.

8. Kovács Lászlóné (2009): Egészséghét, témahét. (Download: 2014.11.13.)

9. Kovátsné N. M. (2006): Projektpedagógia. Új Pedagógiai Szemle 10, pp.68-74

10. Nádasi M. (2003): Projektoktatás. Gondolat Kiadó, Budapest. (Oktatás-módszertani kiskönyvtár)

11. PE Project http://www.ncte.ie/pepp/ (Download: 2014.11.13.) 